\title{
Gastroprotective effect of hydroalcoholic extract from barks of Persea major Kopp (Lauraceae) in rats
}

\author{
Simone A. Cosmo, Bárbara Mayer, Cristina S. Freitas, Cristiane H. Baggio, \\ Maria Consuelo A. Marques*
Departamento de Farmacologia, Setor de Ciências Biológicas, Universidade Federal do Paraná, Caixa Postal 19031, 81531-990, Curitiba, PR, Brazil

\begin{abstract}
RESUMO: "Efeito gastroprotetor do extrato hidroalcoólico da casca da Persea major Kopp (Lauraceae) em ratos". Persea major Kopp (Lauraceae) é utilizada na medicina tradicional para o tratamento de lesões cutâneas e distúrbios gástricos. O objetivo deste estudo é avaliar o potencial gastroprotetor e a toxicidade aguda do extrato bruto hidroalcóolico da Persea major Kopp (EHA). Camundongos Swiss foram tratados com EHA pelas vias oral (v.o.) e intraperitoneal (i.p.) com as doses de 0,125 a $10 \mathrm{~g} / \mathrm{kg}$ e foram observados por 14 dias. $\mathrm{A} \mathrm{DL}_{50}$ calculada após administração i.p. de EHA foi de $480 \mathrm{mg} / \mathrm{kg}$ e superior a $10 \mathrm{~g} / \mathrm{kg}$ pela via oral, em camundongos. Ratos Wistar foram pré-tratados oralmente com EHA $(30,100,300$ e $1000 \mathrm{mg} / \mathrm{kg})$ antes da indução de lesões gástricas por etanol $70 \%(0,5 \mathrm{~mL} / \mathrm{animal}$, v.o. $)$, indometacina $(20 \mathrm{mg} / \mathrm{kg}$, s.c.) e estresse por contenção e hipotermia (durante $3 \mathrm{~h} \mathrm{a} 4{ }^{\circ} \mathrm{C}$ ). O EHA protegeu a mucosa gástrica contra lesões induzidas por etanol, porém não protegeu contra as lesões induzidas por indometacina e estresse. Quando o EHA foi administrado pela via intraduodenal (i.d.), o volume, o pH e a acidez total da secreção gástrica de ratos com ligadura de piloro não foram alterados com diferentes doses do extrato. Os resultados obtidos sugerem um efeito citoprotetor contra ação necrosante direta do etanol pelo extrato bruto hidroalcoólico da Persea major e este efeito não está relacionado com a redução da secreção ácida gástrica.
\end{abstract}

Unitermos: Persea major, Lauraceae, gastroprotetor, etanol.

\begin{abstract}
Persea major Kopp (Lauraceae) is used in folk medicine to treat skin wounds and gastric disorders. This study evaluates the potential of crude hydroalcoholic extract (EHA) as gastroprotective and its acute toxicity. Swiss mice were treated with EHA by oral (p.o.) and intraperitoneal (i.p.) routes with doses of 0.125 to $10 \mathrm{~g} / \mathrm{kg}$ and were observed until 14 days after the administration of the extract. The calculated $\mathrm{LD}_{50}$ of EHA after i.p. administration was 480 $\mathrm{mg} / \mathrm{kg}$ in mice and the $\mathrm{LD}_{50}$ values of EHA by the oral route were calculated to be up to $10 \mathrm{~g} /$ $\mathrm{kg}$ in mice. Wistar rats were orally pretreated with EHA $(30,100,300$ and $1000 \mathrm{mg} / \mathrm{kg})$ before induction of gastric lesions by $70 \%$ ethanol ( $0.5 \mathrm{~mL} / \mathrm{animal}$, p.o.), indomethacin $(20 \mathrm{mg} / \mathrm{kg}$, s.c.) and hypothermic restraint stress (during $3 \mathrm{~h}$ at $4{ }^{\circ} \mathrm{C}$ ). The EHA protected the gastric mucosa against lesions induced by ethanol, but did not reduce the stress- and indomethacin-induced gastric lesions. When the EHA was injected into the duodenal lumen (i.d.), the volume, $\mathrm{pH}$ and total acidity of the gastric secretion of rats with pylorus ligature was not altered with different doses of the extract. Results therefore suggest that the cytoprotective effect of this extract against the direct necrosing action of ethanol and its effect were not related with reduction of gastric acid secretion.
\end{abstract}

Keywords: Persea major, Lauraceae, gastroprotective, ethanol.

\section{INTRODUCTION}

The barks of Persea major Kopp (Lauraceae), popularly know as "Pau de Andrade" and "Abacateiro do Mato", is used in folk medicine in healing of skin wounds and to treat gastric disturbances. The main chemical constituents of the barks of $P$. major include fat acids, amino groups, steroids, triterpens and condensate tannins (Maranho, 1998).

Previous studies demonstrated that the crude hydroalcoholic extract from barks of $P$. major inhibited the intestinal motility in mice when administered intraperitoneally, losing this activity when given orally (Nowacki et al., 2001a). The same extract, in doses over $500 \mathrm{mg} / \mathrm{kg}$, was also capable of protecting the gastric mucosa against $70 \%$ ethanol (Nowacki et al., 2001b). The extract also inhibited the writhing induced by acetic acid (Assis et al., 2003a), neurogenic and inflammatory pain in the formalin test and the paw oedema indicating that the extract can cause analgesic effects and antiedematogenic action (Assis et al., 2003b).

In the present study we tested the crude 
hydroalcoholic extract from barks of Persea major Kopp (Lauraceae) in gastric protection and its acute toxicity.

\section{MATERIAL AND METHODS}

\section{Plant material}

The samples of Persea major were collected in EMBRAPA (Empresa Brasileira de Pesquisa Agropecuária), Colombo, PR, Brazil. The plant was identified by Msc. Olavo Guimarães from the Department of Botany of the Universidade Federal do Paraná (UFPR). A specimen is deposited in the Herbarium of this Institution, under the voucher number 28382.

The barks of Persea major ( $30 \mathrm{~g}$ ) were Soxhletextracted with ethanol $70 \%(300 \mathrm{~mL})$ and, after that, the samples were lyophilized.

\section{Animals}

Female Wistar rats (180-200 g) and Swiss mice (25-30 g) were from UFPR colony and were maintained under standard laboratory conditions (12 hour light/ dark cycle, temperature $22 \pm 2{ }^{\circ} \mathrm{C}$ ). Standard pellet food (Nuvital , Curitiba/PR, Brazil) and water were available ad libitum. The animals were deprived of food for 16 hours prior experiments. All experimental protocols using animals were performed according to the "Principles of Laboratory Animal Care" (NIH Publication 85-23, revised 1985) adopted by UFPR (number approval 161).

\section{Determination of $\mathbf{L D}_{50}$}

Male and female mice $(\mathrm{n}=10)$ were treated with EHA (p.o and i.p) with doses of 0.125, 0.25, 0.35, $0.5,1.0,3.0,5.0,7.5$ and $10 \mathrm{~g} / \mathrm{kg}$. The animals were observed until 14 days after the administration of the EHA.

\section{General activities test}

Male and female mice $(\mathrm{n}=10)$ were treated with $0.125,0.25,0.5,1.0$ and $3.0 \mathrm{~g} / \mathrm{kg}$ of EHA (p.o or i.p). The animals were observed since de first minute after administration and in each $24 \mathrm{~h}$ until the $14^{\text {th }}$ day. The observed signals were noted in a table adapted from Malone (1977).

\section{Induction of acute gastric lesion}

Rats $(\mathrm{n}=6)$ were orally treated with the vehicle (water, $0.1 \mathrm{~mL} / 100 \mathrm{~g}$ ), ranitidine $(75 \mathrm{mg} / \mathrm{kg}$ ) and EHA (30 to $1000 \mathrm{mg} / \mathrm{kg}$ ).

One hour after this treatment gastric lesions were induced by either stress (restraint for $3 \mathrm{~h}$ at $4{ }^{\circ} \mathrm{C}$ ), $70 \%$ ethanol $(0.5 \mathrm{~mL} / \mathrm{animal}$, p.o.) or indomethacin $(20$ mg.kg, s.c.). The animals were killed $3 \mathrm{~h}, 1 \mathrm{~h}$ or $6 \mathrm{~h}$ the inductor agent, respectively (Senay; Levine, 1967; Robert et al., 1979; Djahanguiri, 1969). The stomach was removed and dissected, being the mucosal side gently washed to remove remaining food. Then, it was examined under a stereoscope to determine the number of ulcers and to score the index of mucosal damage (IMD). The IMD adds the points from evaluation of the color, the degree of edema and hemorrhage of the gastric folds, the number of pethechyae $(1$ point $=$ light; 2 points $=$ moderated 3 points $=$ intense, for each parameter) and the points from the number and size of ulcers (number $x$ size). Ranitidine-treated animals were used as positive control experiments (Freitas et al., 2004).

\section{Determination of gastric acid secretion}

A pylorus ligature was carefully done in rats under ether anesthesia and the EHA $(100 \mathrm{mg} / \mathrm{kg}$ to $1000 \mathrm{mg} / \mathrm{kg}$ ) was injected into the duodenal lumen (i.d.). After $4 \mathrm{~h}$, the animals were killed and the gastric secretion collected with a pipette. The final volume and $\mathrm{pH}$ were directly determined after washing the mucosal side of the stomach with $3 \mathrm{~mL}$ of distilled water. The total acidity of the gastric juice was titrated in a digital burette with $0.1 \mathrm{~N} \mathrm{NaOH}$ using phenolphthalein $(2 \%)$ as indicator (Baggio et al., 2005).

\section{Statistical analysis}

Data were expressed as mean \pm s.e.m. Statistical significance of the results was determined using one way analysis of variance (ANOVA) followed by Tukey's test. Data were considered different at a significance level of $\mathrm{p}<0,05$.

For the determination of the $\mathrm{LD}_{50}$, the Lichfield and Wilcoxon method was used (Lichfield; Wilcoxon, 1948).

\section{RESULTS}

\section{Determination of $\mathrm{LD}_{50}$ and general activities test}

The intraperitoneally administration of the EHA in female mice demonstrated a $\mathrm{LD}_{50}$ of $480 \mathrm{mg} / \mathrm{kg}$ lasting up 24 hours since treatment. The animals treated with doses of $0.125,0.25,0.35,0.5,1.0,3.0,5.0,7.5$ and $10 \mathrm{~g} / \mathrm{kg}$ of EHA, p.o., demonstrated $\mathrm{LD}_{50}$ of $10.4 \mathrm{~g} /$ $\mathrm{kg}$, in 14 days, after treatment.

We observed abdominal writhing in all mice that received EHA intraperitoneally after 5 minutes from the administration, as well as the reduction of the motility, in all doses, since 5 minutes until 3 hours after administration of EHA. The same treatment also provoked palpebral ptosis, piloerection and respiratory alterations since 4 minutes until 2 hour after the administration of EHA (i.p.). The animals who received 


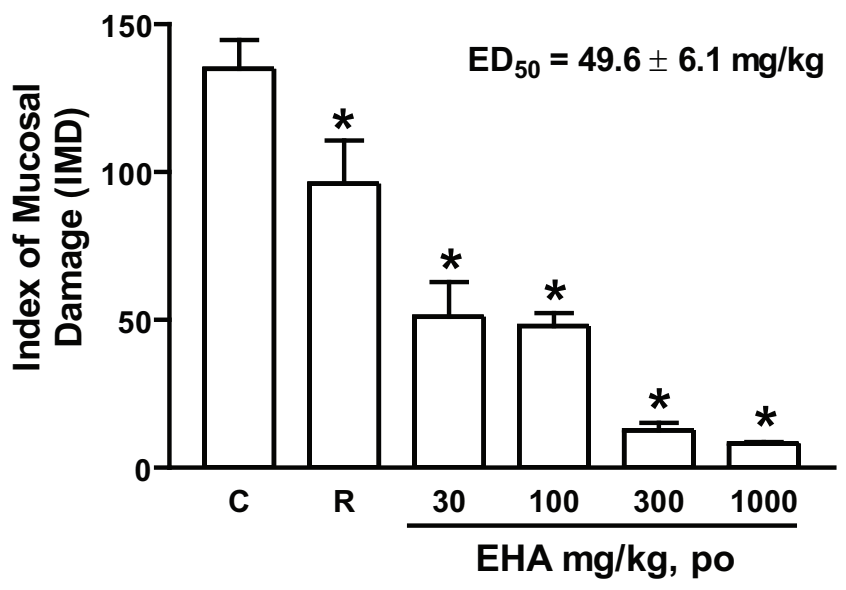

Figure 1. Gastroprotective effects of the EHA. Acute gastric lesions were induced by $70 \%$ ethanol. The animals received vehicle (C = control: water, $0.1 \mathrm{~mL} / 100 \mathrm{~g}$, p.o.), ranitidine (R, $75 \mathrm{mg} / \mathrm{kg}$, p.o.) and EHA (30-1000 mg/kg, p.o.) 1 h before induction of acute gastric lesions. The results are expressed as mean \pm standard error of mean $(n=6)$. Statistical comparison was performed using analysis of variance (ANOVA) followed by Tukey's test $(* \mathrm{p}<0.05)$.

Table 1. Effects of the EHA on indomethacin- and stress-induced gastric lesions.

\begin{tabular}{lcc}
\hline \multicolumn{1}{c}{ Groups } & Indomethacin & Stress \\
\hline Injured Control & $75.5 \pm 8.4$ & $22.3 \pm 5.6$ \\
Ranitidine $60 \mathrm{mg} / \mathrm{kg}$ & $6.4 \pm 0.5 *$ & $7.3 \pm 2.0^{*}$ \\
EHA $30 \mathrm{mg} / \mathrm{kg}$ & $52.0 \pm 10.3$ & n.d. \\
EHA $100 \mathrm{mg} / \mathrm{kg}$ & $63.2 \pm 8.7$ & $23.9 \pm 5.3$ \\
EHA $300 \mathrm{mg} / \mathrm{kg}$ & $51.7 \pm 12.1$ & $25.2 \pm 4.9$ \\
EHA $1000 \mathrm{mg} / \mathrm{kg}$ & $65.1 \pm 6.0$ & $21.4 \pm 4.1$ \\
\hline
\end{tabular}

n.d.- not determined

* Statistically different from control group $(\mathrm{p}<0.05)$

Table 2. Quantitative analysis of coccineone-B present in root samples of wild growing plant.

\begin{tabular}{cccc}
\hline Groups & $\begin{array}{c}\text { Volume } \\
(\mathrm{mL})\end{array}$ & $\begin{array}{c}\text { Total Acidity } \\
\left(\mathrm{mEq}\left[\mathrm{H}^{+}\right] / \mathrm{L}\right)\end{array}$ & $\mathrm{pH}$ \\
\hline Control & $7.7 \pm 0.6$ & $0.068 \pm 0.004$ & $1.7 \pm 0.1$ \\
Ranitidine $60 \mathrm{mg} / \mathrm{kg}$ & $6.1 \pm 0.5$ & $0.042 \pm 0.005$ & $2.3 \pm 0.2$ \\
EHA $100 \mathrm{mg} / \mathrm{kg}$ & $6.7 \pm 0.8$ & $0.060 \pm 0.008$ & $1.9 \pm 0.2$ \\
EHA $300 \mathrm{mg} / \mathrm{kg}$ & $6.5 \pm 0.8$ & $0.050 \pm 0.011$ & $1.9 \pm 0.2$ \\
EHA $1000 \mathrm{mg} / \mathrm{kg}$ & $5.9 \pm 0.5$ & $0.057 \pm 0.003$ & $2.0 \pm 0.1$ \\
\hline
\end{tabular}

$\mathrm{Nd}=$ not detected.

the doses 1.0 and $3.0 \mathrm{~g} / \mathrm{kg}$, i.p. demonstrated alienation to the environment and prostration.

When the administration of the EHA was orally, similar effects were observed to that provoked when given intraperitoneally, distinct only on the time of the occurrence of the effects, and in the dose needed for the induction of the effects.

\section{Effect on gastric lesions}

Oral treatment with EHA protected rats against gastric lesions induced by ethanol with $\mathrm{ED}_{50}=49.6$ 
$\pm 6.1 \mathrm{mg} / \mathrm{kg}$ (injured control group value $=134 \pm 10$, mean \pm s.e.m.). Ranitidine reduced the IMD to $96 \pm 14$, 7 (Figure 1). However, the EHA (doses of 30, 100, 300 and $1000 \mathrm{mg} / \mathrm{kg}$, p.o.) did not protect against lesions induced by indomethacin and stress (injured control group value $=75.5 \pm 8.4$ and $22.3 \pm 5.6$, respectively). Ranitidine reduced the IMD to $6.4 \pm 0.5$ and $7.3 \pm 2.0$, respectively (Table 1).

\section{Effects on gastric acid secretion}

The intraduodenal administration of EHA (30, 100,300 and $1000 \mathrm{mg} / \mathrm{kg}$ ) and ranitidine did not alter the volume, $\mathrm{pH}$ and the acidity of the gastric content after 4 hours of pylorus ligature (control values $=7.7$ $\pm 0.6 \mathrm{~mL}, 1.7 \pm 0.1$ and $0.068 \pm 0.004 \mathrm{mEq}\left[\mathrm{H}^{+}\right] / \mathrm{mL}$, respectively. (Table 2 ).

\section{DISCUSSION}

The Persea genus has been used for the treatment of many diseases, such as skin's inflammation, gastric disturbances, and as diuretic (Tôrres et al., 2005; Agra et al., 2007). The phytochemical studies demonstrated a great amount of fat acids, amino groups, steroids and tannins. It's well known that the last three groups, specially tannins, may be associated with healing process, and that may explain the folk utilization of the barks of $P$. major to treat cutaneous wounds. Therefore, we assessed the possible gastroprotective activity of the EHA. The antiulcerogenic activity of EHA was tested through in vivo models of acute gastric lesions and, to evaluate the antisecretory activity, the pyloric ligature model was used. The test for determination of acute toxicity $\left(\mathrm{LD}_{50}\right)$, carried out on mice, indicated that EHA is less toxic when given orally (same route of administration as used in folk medicine) since no animal deaths were observed with doses from 5.0 to $7.5 \mathrm{~g} / \mathrm{kg}$. In the general activities test, it was observed indicative signals that EHA, independently of administration way (oral or intraperitoneal), produces depression of Central Nervous System (CNS) activities. The EHA did not protect the gastric mucosa of rats against indomethacinand stress- induced gastric lesions, suggesting that $P$. major did not have influence on factors involved in these gastric lesions pathology. However, we observed a protective action of the EHA against ethanol-induced gastric lesions suggesting that EHA has an important cytoprotective action against the direct necrosing action of ethanol. The antisecretory activity of EHA was analyzed according Shay et al. (1945). After the treatment with EHA, it was not observed variation on the volume of the secretion after 4 hours from the procedure of pylorus ligature, leading to the fact that EHA does not act in the mechanism that control the production of gastric acid, such antagonism of $\mathrm{H}_{2}$ receptors and $\mathrm{H}^{+}$, $\mathrm{K}^{+}$-ATPase inhibition.

\section{CONCLUSION}

Results obtained after oral administration of the crude hydroalcoholic extract from barks of Persea major Kopp (Lauraceae) suggested that this plant has cytoprotective action against ethanol-induced gastric lesion. However, it did not protect against indomethacinand stress- induced gastric lesions as well as did not alter the gastric secretion during the 4 hour of pylorus ligature.

\section{REFERENCES}

Agra MF, França PF, Barbosa-Filho JM 2007. Synopsis of the plants known as medicinal and poisonous in Northeast of Brazil. Rev Bras Farmacogn 17: 114-140.

Assis LNSP, Vosguerau MC, Bornato F, Corso CF, Cintra T, Cosmo SA, Maranho LT, Nowacki LC 2003. Propriedade antinociceptiva do extrato bruto hidroalcoólico de Persea major nas contorções abdominais induzidas por ácido acético. $X X X V$ Congresso Brasileiro de Farmacologia. Águas de Lindóia, Brasil.

Assis LNSP, Vosguerau MC, Bornato F, Corso CF, Cintra T, Cosmo SA, Maranho LT, Nowacki LC 2003. Avaliação da ação analgésica e antiedematogênica do extrato bruto de Persea major. XXXV Congresso Brasileiro de Farmacologia. Águas de Lindóia, Brasil.

Baggio CH, Otofuji GM, Souza WM, Santos CAM, Torres LMB, Rieck L, Marques MCA, Mesia-Vela S 2005. Gastroprotective mechanisms of indole alkaloids from Himatanthus lancifolius. Planta Med 71: 733-738.

Djahanguiri B 1969. The production of acute gastric ulceration by indomethacin in rats. Scand J Gastroenterol 4: 265.

Freitas CS, Baggio CH, Silva-Santos JE, Rieck L, Santos CAM, Côrrea Júnior C, Ming LC, Cortez DAG, Marques MCA 2004. Involvement of nitric oxide in the gastroprotective effects of an aqueous extract of Pfaffia glomerata (Spreng) Pedersen, Amaranthaceae, in rats. Life Sci 74: 1167-1179.

Litchfield JT, Wilcoxon F 1948. Simplied method of evaluating dose-effect experiments. American Cynamid Company, Stanford Research Laboratory. Connecticut.

Malone MH 1977. Pharmacological approaches to natural products screening and evaluation. In: Wagner $\mathrm{H}$, Wolf $\mathrm{P}$ (eds.). Natural products and plant drugs with pharmacological, biological or therapeutical activity. Berlin: Springer-Verlag, p. 23-53.

Maranho LT 1998. Contribuição ao estudo botânico, fitoquímico, farmacológico e microbiológico de Persea major Kopp (Lauraceae). Curitiba, 85p. Dissertação de Mestrado - Setor de Ciências Biológicas, Universidade Federal do Paraná.

Nowacki LC, Cruz E, Oliveira I, Lago Neto J, Maranhos L 2001. Efeito do extrato hidroalcoólico de Persea major (Lauraceae) sobre o trato gastrointestinal 
de camundongos e ratos. XVI Reunião Anual da Federação de Sociedades de Biologia Experimental. Caxambu, Brasil.

Nowacki LC, Oliveira I, Cruz E 2001. Avaliação do suco gástrico de ratos tratados com extrato hidroalcoólico de Persea major intraduodenal. XVIReunião Anual da Federação de Sociedades de Biologia Experimental. Caxambu, Brasil.

Robert A, Nezamis JE, Lancaster C, Hauchar AJ 1979. Cytoprotection by prostaglandins in rats. Prevention of gastric necrosis produced by alcohol, $\mathrm{HCl}, \mathrm{NaOH}$, hypertonic $\mathrm{NaCl}$ and thermal injury. Gastroenterology 77: 433-443.

Senay SE, Levine RJ 1967. Synergism between cold and restraint for rapid production of stress ulcer in rats. Proc Soc Exp Biol Med 124: 1221-1223.

Shay H, Komarov SA, Fels SE, Meraze D, Gruenstein M, Siplet H 1945. A simple method for the uniform production of gastric ulceration in rat. Gastroenterology 5: 43-61.

Tôrres AR, Oliveira RAG, Diniz MFFM, Araújo EC 2005. Estudo sobre o uso de plantas medicinais em crianças hospitalizadas da cidade de João Pessoa: riscos e benefícios. Rev Bras Farmacogn 15: 373-380. 